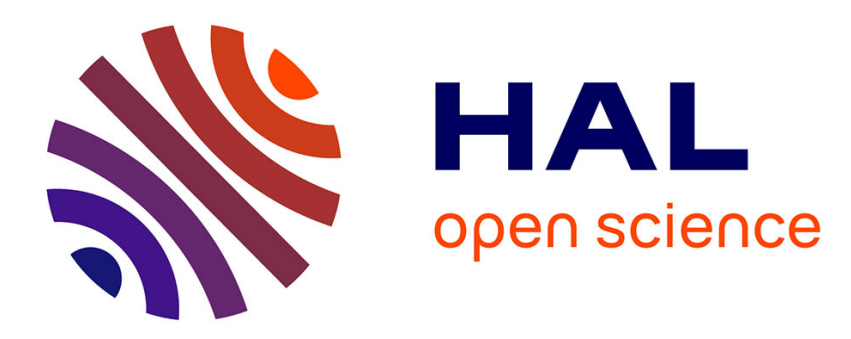

\title{
The lysins of bacteriophages infecting lactic acid bacteria
}

S. Sable, Sylvie S. Lortal

\section{To cite this version:}

S. Sable, Sylvie S. Lortal. The lysins of bacteriophages infecting lactic acid bacteria. Applied Microbiology and Biotechnology, 1995, 43 (1), pp.1-6. hal-02712188

\section{HAL Id: hal-02712188 \\ https://hal.inrae.fr/hal-02712188}

Submitted on 1 Jun 2020

HAL is a multi-disciplinary open access archive for the deposit and dissemination of scientific research documents, whether they are published or not. The documents may come from teaching and research institutions in France or abroad, or from public or private research centers.
L'archive ouverte pluridisciplinaire HAL, est destinée au dépôt et à la diffusion de documents scientifiques de niveau recherche, publiés ou non, émanant des établissements d'enseignement et de recherche français ou étrangers, des laboratoires publics ou privés. 


\section{The lysins of bacteriophages infecting lactic acid bacteria}

Received: 29 March 1994/Accepted: 29 July 1994

\begin{abstract}
This short review highlights the complete absence of literature on lysins of bacteriophages infecting species like $S$. salivarius subsp. thermophilus, Pediococcus and Leuconostoc species, L. helveticus, L. acidophilus, L. plantarum and L. brevis, which are also widely used in the dairy industry. The lysins described share some similar biochemical characteristics: optimal $\mathrm{pH}$ and temperature, site of hydrolysis inside the peptidoglycan, and some activators and inhibitors. The cloning of the genes encoding these lysins only began in the last few years and four of them have been completely sequenced. In the future, these lysin genes could be interestingly compared to the host autolysin(s) gene(s). By contrast, the passage of phage lysins through the cytoplasmic membrane of the host cell in order to reach the peptidoglycan (via a signal sequence or the presence of a holin) seems not to be clearly resolved. The presence of a second open-reading frame upstream from the gene of the lysin, enabling a putative holin to be encoded, has already been suggested. No doubt our ever increasing knowledge about bacteriophage genome organization will help to elucidate this question. Meanwhile the obtention of a Lactococcus strain with an autolytic phenotype, using a bacteriophage lysin gene, as well as the successful use of purified PL1 lysin to obtain protoplasts of $L$. case $i$ encourage us to continue to explore the field of bacteriophage lysins.
\end{abstract}

S. Sable

Université La Rochelle, Laboratoire de Microbiologie appliqué; Avenue Marillac, 17042 La Rochelle cedex 01, France

S. Lortal (ब)

INRA, Laboratoire de Recherches de Technologie Laitière, 65 rue de St. Brieuc, 35042 Rennes cedex, France.

Fax: + 33-99.28.53.50

\section{Introduction}

Lactic acid bacteria are widely used in a variety of dairy fermentation processes. They contribute to the flavour, the texture and the protection of the product from spoilage microorganisms. Nevertheless, they are susceptible to bacteriophage infections, as described for the first time in 1935 (Whitehead and Cox 1935). Since that time, numerous reports have described the morphology (Accolas and Spillman 1979a, b; Sechaud et al. 1988; Sechaud 1990), the genome (Teuber and Lembke 1983; Mata et al. 1986; Jarvis et al. 1991) and the adsorption on the bacterial cell (Yokokura 1977; Ishibashi et al. 1982; De Vos et al. 1984; Valyasevi et al. 1990) of these bacteriophages. Resistance mechanisms of bacteria have received particular attention (Chopin et al. 1984; Watanabe et al. 1984b; Gautier and Chopin 1987; Klaenhammer 1987; Hill et al. 1990) in order to construct bacteriophage-resistant starters for the dairy industry (Sanders et al. 1986).

For temperate as well as for virulent bacteriophages, the release of native bacteriophage particles implies a hydrolysis step of the bacterial cell wall by a lytic enzyme known as the bacteriophage lysin. This lysin is probably also implicated in the injection of the DNA phage into the cell. This key enzyme of the bacteriophage propagation has been extensively studied in some gram-positive bacteria like $B$. subtilis (Ward et al. 1982; Garvey et al. 1986) and $S$. pneumoniae (Garcia et al. 1987; Romero et al. 1990a) and in the gram-negative bacteria $E$. coli (Young 1992). Paradoxically the lysins produced by the bacteriophges infecting lactic acid bacteria have received little attention. The purification and biochemical characterization of these enzymes, and a better knowledge of their regulation, would perhaps contribute to stopping or to slowing down their lytic action in industrial conditions. In addition, these enzymes, once they have been partially purified, could be used to hydrolyse the cell wall of some lactic acid bacteria, resistant to hen egg-white 
lysozyme, in order to obtain protoplasts or to fragilize the cells efficiently. Moreover, the construction of strains with an "autolytic" phenotype with the gene encoding the bacteriophage lysin (Heinrich and Plapp 1984), as suggested by Shearman et al. (1989) for Lactococcus species, implies the characterization of the gene and of the enzyme itself. Such strains, releasing their intracellular enzymes more efficiently (peptidases, proteases, lipases; all or some of them possibly amplified in the future) in the curd, could be useful in a strategy of accelerated ripening.

Finally, in the course of a more general view of lytic enzymes, Garcia et al. (1987) and Romero et al. (1990b) have suggested an evolutionary relationship between the bacteriophage lysins and the autolysins of the host cells. This relationship would be interesting to observe in lactic acid bacteria also, even if for the moment no autolysins have actually been purified in these microorganisms.

The aim of this review is to summarize the available literature on the lysins of bacteriophages infecting lactic acid bacteria.

\section{The lysins of bacteriophages infecting Lactococcus species}

Several lysins of bacteriophages infecting the species Lactococcus lactis (previously named Streptococcus lactis; Schleifer et al. 1985) have been described (Table 1). Four of them $[\mathrm{C} 2, \mathrm{C} 10, \mathrm{ML} 3, \mathrm{C} 2(\mathrm{w})]$ have been partially purified directly from cell lysates by ammonium sulphate precipitation generally followed by chromatographic steps (Reiter and Oram 1963; Oram and Reiter 1965; Tourville and Johnstone 1966; Tourville and Tokuba 1967; Mullan and Crawford 1985a, b). The purified enzymes showed similar values for optimal $\mathrm{pH}$ and temperature, as well as some similar activators and inhibitors (Table 2). Moreover, the lysins ML3 and $\mathrm{C} 2(\mathrm{w})$ were found to be muramidases (cleaving the $\beta 1-4$ $\mathrm{N}$-acetylmuramic-acid- $\mathrm{N}$-acetylglucosamine linkage in the peptidoglycan (EC 50.1.2.3.17). They were all more sensitive to heat when compared to the phage producer; on the other hand they were less strain-specific, as demonstrated by their lytic spectra (Table 3). Indeed several strains of group D streptococci and also strains of $L$. lactis, all resistant to the bacteriophage, were sensitive to the partially purified lysins. It could be noticed that C10 lysin was also active against Micrococcus luteus. Some authors have emphasized the importance of this lytic spectrum in a mixed starter system (Naylor and Czulak 1956; Mullan and Crawford 1985b). They demonstrated that the lactic acid production could be perturbed by a phage lysin even if some strains constituting the mixed starter were resistant to the bacteriophage itself. These authors also suggested the use of these partially purified lysins to obtain protoplasts of $L$. lactis, in particular for strains resistant to 
Table 2 Heat denaturation, activators and inhibitors of the partially purified lysins

\begin{tabular}{|c|c|c|c|c|}
\hline Lysins & $\begin{array}{l}\text { Inactivation } \\
\text { by heating }\end{array}$ & Activators & Inhibitors & References \\
\hline ML3, C10 & $T>37^{\circ} \mathrm{C}$ & $\begin{array}{l}\mathrm{Na}^{+}(0.15 \mathrm{M}), \mathrm{Li}^{+}, \mathrm{NH}_{4}^{+} \\
\mathrm{Ca}^{2+}, \mathrm{Mg}^{2+}\end{array}$ & $\mathrm{Na}^{+}>0.15 \mathrm{M}$ & Oram and Reiter 1965 \\
\hline $\mathrm{C} 2, \mathrm{C} 10$ & $56^{\circ} \mathrm{C} / 20 \mathrm{~min}$ & $\mathrm{NaCl}, \mathrm{LiCl}, \mathrm{CaCl}_{2}$ & $\begin{array}{l}\text { p-Chloromercuribenzoate }(0.02 \mathrm{mM}) \\
\text { iodoacetamide }(0.01 \mathrm{M})\end{array}$ & Tourville and Tokuda 1967 \\
\hline $\mathrm{C} 2(\mathrm{~W})$ & $\begin{array}{l}47^{\circ} \mathrm{C} / 5 \min \\
57^{\circ} \mathrm{C} / 1 \min \end{array}$ & $\begin{array}{l}\mathrm{Na}^{+}(0.1 \mathrm{M}), \mathrm{K}^{+}(0.1 \mathrm{M}) \\
\mathrm{Mn}^{2+}(3 \mathrm{mM}), \mathrm{Ca}^{2+}(5 \mathrm{mM}) \\
\mathrm{Co}^{2+}(8 \mathrm{mM}), \mathrm{Mg}^{2+}(5 \mathrm{mM})\end{array}$ & $\begin{array}{l}\mathrm{Na}^{+}>1 \mathrm{M}, \mathrm{K}^{+}>1 \mathrm{M} \\
\mathrm{Co}^{2+}(30 \mathrm{mM}) \\
p \text {-chloromercuribenzoate }(0.01 \mathrm{mM}) \\
\text { glutathione }(0.06 \mathrm{M}) \\
\text { urea }(1 \mathrm{M})\end{array}$ & Mullan and Crawford $1985 \mathrm{a}, \mathrm{b}$ \\
\hline PL1 & - & - & $\begin{array}{l}\mathrm{Cu}^{2+}(1 \mathrm{mM}), \mathrm{Fe}^{3+}(1 \mathrm{mM}), \\
\mathrm{Cd}^{2+}(1 \mathrm{mM}) \text { monoiodoacetate }(1 \mathrm{mM}) \\
p \text {-chloromercuribenzoate }(10 \mathrm{mM}) \\
\text { diisopropylfluorophosphate }(1 \mathrm{mM}) \\
\text { phenylmethylsulphonylfluoride }(10 \mathrm{mM}) \\
\text { O-phenanthroline }(0.1 \mathrm{mM})\end{array}$ & $\begin{array}{l}\text { Watanabe et al. } 1984 \\
\text { ) }\end{array}$ \\
\hline
\end{tabular}

hen egg-white lysozyme. For that purpose, conditions affecting the lysis of group $\mathrm{N}$ streptococci by the purified $\phi \mathrm{C} 2(\mathrm{w})$ lysin were determined (carbon source, growth temperature, lyophilisation of the cells) (Mullan and Crawford 1985c). In a similar manner, the partially purified lysin of the bacteriophage $\phi v \mathrm{ML} 3$ has been used to liberate cell wall proteinases in lactic streptococci (Thomas et al. 1974).

The gene encoding the lysin of $\phi \mathrm{vML} 3$ has been recently cloned using an $E$. coli/bacteriophage $\lambda$ host vector system (Shearman et al. 1989). The sequence of the gene corresponded to a protein of 187 amino acids with a deduced molecular mass of $21090 \mathrm{Da}$; this was coherent with the $24 \mathrm{kDa}$ protein expressed by $E$. coli (as determined by sodium dodecyl sulphate/polyacrylamide gel electrophoresis, SDS-PAGE). The ML3 lysin was active on a wide range of Lactococcus strains but lacked homology with known lytic enzymes. Interestingly, significant homology was shown with protein 15 of the bacteriophage PZA infecting B. subtilis, which is involved in phage morphogenesis. Thus, the ML3 lysin could possibly fulfil a second function in phage maturation. The ML3 lysin gene has been located on the restriction map of the $\phi \mathrm{vML} 3$ genome in the central region (Shearman et al. 1991). Moreover, attempts to clone it in L. lactis have recently been successful (Shearman et al. 1992) leading to a strain with an "autolytic" phenotype. The lysis occurred only after the exponential growth phase and the strain can now be tested in a flavour-acceleration strategy for cheese ripening.

Recently the bacteriophage $\mathrm{c} 2$ lysin was expressed in E. coli in an identical manner to the ML3 lysin (Ward et al. 1993). The DNA sequence obtained was very similar, with a number of silent substitutions, and an apparent deletion altering the $\mathrm{C}$ terminus of the pro- tein. In this work, a codon-usage table for the lysin genes of several bacteriophages was also provided.

On the other hand, the gene (lyt $A$ ) encoding the lysin (LytA) of the bacteriophage $\phi \mathrm{US} 3$ has been cloned and expressed in E. coli (Patteeuw and De Vos 1992). The nucleotide sequence of $l y t A$ showed an open-reading frame of $774 \mathrm{bp}$ corresponding to a protein of 258 amino acids with a deduced molecular mass of $28977 \mathrm{Da}$; this was in agreement with the $29 \mathrm{kDa}$ protein expressed by $E$. coli. Interestingly, the amino acid sequence of LytA was similar to that of the autolysin of $S$. pneumoniae. This fact suggests that the lysin could be an amidase, the first one among the lysins already described (Table 1).

\section{The lysins of bacteriophages infecting Lactobacillus species}

In the case of the dairy lactobacilli, the lysin of the phage PL1 infecting Lactobacillus casei is the only one to be partially purified directly from a cell lysate (Watanabe et al. 1984a; Hayashida et al. 1987). The optimum $\mathrm{pH}$, inhibitors and specificity were similar to those of the lysins of the bacteriophages infecting $\mathrm{Lac}$ tococcus lactis (Tables 1, 2). The lytic spectrum has been tested on very few species and the lysin seems to be specific to the host strain, and to the $L$. casei species (Table 3). In addition, the $\mathrm{N}$-terminal sequence of the purified PL1 lysin was determined up to 27 amino acid residues (AY?INKEFALGANEG?KZVAN?LYIIL). Interestingly, the PL1 lysin has been used to obtain protoplasts of $L$. casei (Watanabe et al. 1987) and these protoplasts were recently well transfected by PL1 phage DNA (Watanabe et al. 1992). In 1986, the genome of the virulent LL-H phage infecting $L$. lactis 
Table 3 Lytic spectra of the isolated lysins; the number of strains tested is shown in parentheses

\begin{tabular}{|c|c|c|c|c|c|c|c|c|c|}
\hline \multirow[t]{2}{*}{ Species } & \multicolumn{9}{|l|}{ Lysins } \\
\hline & ML3 & $\mathrm{C} 10^{\mathrm{a}}$ & $\mathrm{C} 2$ & $\mathrm{C} 10^{\mathrm{b}}$ & $\mathrm{C} 2(\mathrm{w})$ & LL-H ${ }^{c}$ & LytA $^{c}$ & PL1 & $\begin{array}{l}\text { Leuconostoc } \\
\text { lysin }\end{array}$ \\
\hline $\begin{array}{c}\text { Group N streptococci } \\
\text { Lactococcus cremoris } \\
\text { lactis } \\
\text { diacetylactis } \\
\text { Streptococcus thermophilus }\end{array}$ & $\begin{array}{l}+(5) \\
+(3) \\
+(1)\end{array}$ & $\begin{array}{l}+(5) \\
+(3) \\
+(1)\end{array}$ & + & + & $\begin{array}{l}+(8) \\
+(6) \\
+(2) \\
-(2)\end{array}$ & & $\begin{array}{l}+(12) \\
+(22)-(1)\end{array}$ & & $\begin{array}{l}-(1) \\
-(1) \\
-(1)\end{array}$ \\
\hline $\begin{array}{l}\text { Group D streptococci } \\
\text { Streptococcus bovis } \\
\text { zymogenes } \\
\text { durans } \\
\text { liquefaciens } \\
\text { faecalis } \\
\text { faecium }\end{array}$ & $\begin{array}{l}+(1) \\
+(1) \\
+(1) \\
+(1) \\
+(1)\end{array}$ & $\begin{array}{l}+(1) \\
+(1) \\
+(1) \\
+(1) \\
+(1)\end{array}$ & & & $\begin{array}{l}+(2) \\
+(2) \\
+(1) \\
+(1)\end{array}$ & & & & \\
\hline $\begin{array}{c}\text { Group A streptococci } \\
\text { Streptococcus pyogenes } \\
\text { mutans }\end{array}$ & $-(3)$ & $-(3)$ & & & & & & $\begin{array}{l}-(1) \\
-(4)\end{array}$ & \\
\hline $\begin{array}{l}\text { Group B streptococci } \\
\text { Streptococcus agalactiae }\end{array}$ & $-(3)$ & $-(3)$ & & & & & & & \\
\hline $\begin{array}{l}\text { Group C streptococci } \\
\text { Streptococcus dysgalactiae } \\
\text { Lactobacillus casei } \\
\text { arabinosus } \\
\text { (plantarum) } \\
\text { bulgaricus } \\
\text { fermentum } \\
\text { lactis } \\
\text { helveticus }\end{array}$ & $-(3)$ & $-(3)$ & & & $\begin{array}{l}-(2) \\
- \\
-\end{array}$ & $\begin{array}{l}- \\
+(6)-(4) \\
-(4) \\
+(3)-(3)\end{array}$ & & $\begin{array}{l}+(2) /-(2) \\
-(1)\end{array}$ & $-(1)$ \\
\hline $\begin{array}{l}\text { Leuconostoc lactis } \\
\qquad \begin{array}{l}\text { dextranicum } \\
\text { cremoris } \\
\text { mesenteroides }\end{array}\end{array}$ & & & & & $\begin{array}{l}-(2) \\
-(2) \\
-(2)\end{array}$ & & & & $\begin{array}{l}+(1) \\
+(11)-(4) \\
+(6)-(1) \\
+(4)(1)\end{array}$ \\
\hline Micrococcus luteus & - & & & + & - & & & & \\
\hline $\begin{array}{l}\text { E. coli } \\
\text { Staphylococcus aureus } \\
\text { Bacillus megaterium } \\
\text { Bacillus subtilis } \\
\text { Aerobacter sp. } \\
\text { Klebsiella } \mathrm{sp} . \\
\text { Sarcina lutea }\end{array}$ & & & & - & - & + & & & $-(1)$ \\
\hline
\end{tabular}

a Oram and Reiter 1965

b Tourville and Tokuda 1967

c Lysin expressed by E. coli after cloning

was characterized and the gene coding for the phage lysin cloned in E. coli (Trautwetter et al. 1986). The LL-H lysin expressed by $E$. coli showed a large lytic spectrum (Table 3 ) since it was able to lyse $B$. subtilis.

Recently another gene (lys $A$ ) encoding the lysin of the temperature bacteriophage mv1 infecting $L$. delbrueckii subsp. bulgaricus has been sequenced after cloning in $E$ coli (Boizet et al. 1990). The molecular mass of the deduced protein was $21120 \mathrm{Da}$. This was coherent with the apparent molecular mass of the lytic protein expressed by E. coli $(24 \mathrm{kDa})$. Moreover, the lysin produced by $E$. coli was active on some strains of L. delbrueckii subsp. bulgaricus, but also on strains of L. helveticus and S. salivarius subsp. thermophilus. No lytic effect was detected on Lactococcus strains. Because of the significant homology between the N-terminal regions of the LysA lysin, the muramidase of Chalaropsis (Flech et al. 1975) and the muramidase of the Cp1 phage infecting Streptococcus pneumoniae (Garcia et al. 1988), Boizet et al. have suggested that LysA was also a muramidase. It could be noticed that no homology was noted between the N-terminal 
sequence of LysA and that of PL-1, which was shown to be a muramidase by biochemical assays (Table 1). In addition, no homology was observed between the complete amino acid sequences of ML3 or LytA (Table 1) and that of LysA. Taking into account the absence of characteristic promoter sequences and the presence of an open-reading frame with unknown function upstream from the $l y s A$ gene, Boizet et al. (1990) suggested that this gene was part of an operon. This was substantiated by the genome analysis of another temperate bacteriophage (mv4), closely related to the bacteriophages mv1 and LL-H (Mata et al. 1986), and infecting L. delbrueckii subsp. bulgaricus; the operon implicated in the cell lysis (lysB-lys $A$ ) was located on the restrictin map of the mv4 genome (Lahbib-Mansais et al. 1992).

\section{The lysins of bacteriophages infecting other species in lactic acid bacteria}

To our knowledge, the lysins of bacteriophages infecting the species Streptococcus salivarius subsp. thermophilus as well as those infecting pediococci have not been described. The lysin of a bacteriophage (46-8-56) infecting strains of Leuconostoc dextranicum was partially purified by ammonium sulphate precipitation (Shin and Sato 1980). The lytic spectrum of this enzyme on the main group of lactic acid bacteria was prepared (Table 3), and was again much wider than the phage spectrum itself.

Acknowledgements The authors are indebted to Cecile Guinard for corrections to the English, and to Riwanon Lemé for critical reading of the manuscript. This paper is dedicated to the memory of Charles Borelli.

\section{References}

Accolas JP, Spillmann H (1979a) Morphology of bacteriophages of Lactobacillus bulgaricus, L. lactis and L. helveticus. J Appl Bacteriol 47:309-319

Accolas JP, Spillman H (1979b) The morphology of six bacteriophages of Streptococcus thermophilus. J Appl Bacteriol 47:135-144

Boizet B, Lahbib-Mansais Y, Dupont L, Ritzenthaler P, Mata M (1990) Cloning, expression and sequence analysis of an endolysin-encoding gene of Lactobacillus bulgaricus bacteriophage mv1. Gene 94:61-67

Chopin A, Chopin MC, Moillo-Batt A, Langella P (1984) Two plasmids determined restriction and modification systems in Streptococcus lactis. Plasmid 11:260-263

De Vos WM, Underwood HM, Davies FL (1984) Plasmid encoded bacteriopohage resistance in Streptococcus cremoris SK11. FEMS Microbiol Lett 23:175-178

Flech JW, Inagami T, Hash JH (1975) The $N, O$-diacetylmuramidase of Chalaropsis species. J Biol Chem 25:3713-3720

Garcia JL, Garcia E, Arraras A, Garcia P, Ronda C, Lopez R (1987) Cloning, purification, and biochemical characterization of the pneumococcal bacteriophage Cp-1 lysin. J Virol 61:2573-2580

Garcia E, Garcia JL, Garcia P, Arraras A, Sanchez-Puelles JM, Lopez R (1988) Molecular evolution of lytic enzymes of Strepto- coccus pneumoniae and its bacteriophages. Proc Natl Acad Sci USA 85:914-918

Garvey KJ, Saedi MS, Ito I (1986) Nucleotide sequence of Bacillus phage $\phi 29$ genes 14 and 15: homology of gene 15 with over phage lysozymes. Nucleic Acids Res 14:10001-10008

Gautier M, Chopin MC (1987) Plasmid determined systems for restriction and modification activity and abortive infection in Streptococcus cremoris. Appl Environ Microbiol 53:923-927

Hayashida M, Watanabe K, Muramatsu T. Goto MA (1987) Further characterization of PL-1 phage-associated $N$-acetylmuramidase of Lactobacillus casei. J Gen Microbiol 133:1343-1349

Henrich B, Plapp R (1984) Use of a cloned bacteriophage gene to disrupt bacteria. J Biochem Biophys Methods 10:25-34

Hill C, Miller LA, Klaenhammer TR (1990) Cloning, expression and sequence determination of bacteriophage fragment encoding bacteriophage resistance in Lactococcus lactis. J Bacteriol 172:6419-6426

Ishibashi K, Takesue S, Watanabe K, Oishi K (1982) Use of lectines to characterize the receptor sites for bacteriophage PL-1 of Lactobacillus casei. J Gen Microbiol 128:2251-2259

Jarvis AW, Fitzgerald GF, Mata M, Mercenier A, Neve H, Powell IB, Ronda C, Saxelin M, Teuber M (1991) Species and type phages of lactococcal bacteriophages. Intervirology 32:2-9

Klaenhammer TR (1987) Plasmid-directed mechanisms for bacteriophage defense in lactic streptococci. FEMS Microbiol Rev 46:313-325

Lahbib-Mansais Y, Mata M, Ritzenthaler P (1988) Molecular taxonomy of Lactobacillus phages. Biochimie 70:429-435

Lahbib-Mansais Y, Boizet B, Dupont L, Mata M, Ritzenthaler $P$ (1992) Characterization of a temperate bacteriophage of Lactobacillus delbrueckii subsp. bulgaricus and its interactions with the host cell chromosome. J Gen Microbiol 138:1139-1146

Mata M, Trautwetter A, Luthaud G, Ritzenthaller P (986) Thirteen virulent and temperature bacteriophages of Lactobacillus bulgaricus and Lactobacillus lactis belong to a single DNA homology group. Appl Environ Microbiol 52:429-435

Mullan WMA, Crawford RJM (1985a) Partial purification and some properties of $\phi \mathrm{C}_{2}(\mathrm{w})$ lysin, a lytic enzyme produced by phage-infected cells of Streptococcus lactis $\mathrm{C}_{2}$. J Dairy Res 52:123-138

Mullan WMA, Crawford RJM (1985b) Lysin production by $\phi \mathrm{C}_{2}(\mathrm{w})$, a prolate phage for Streptococcus lactis $\mathrm{C}_{2}$. J Dairy Res 52:113-121

Mullan WMA, Crawford RJM (1985c) Factors affecting the lysis of group N streptococci by phage lysin. Milchwissen 40:342-345

Naylor J, Czulak J (1956) Host phage relationship of cheeese starter organisms. II. Effect of phage activity on heterologous strains of lactic streptococci. J Dairy Res 23:126-130

Oram JD, Reiter B (1965) Phage-associated lysins affecting group $\mathrm{N}$ and group D streptococci. J Gen Microbiol 40:57-70

Platteeuw C, De Vos WM (1992) Location, characterization and expression of lytic enzyme-encoding gene, lytA, of Lactococcus lact is bacteriophage $\phi \mathrm{US} 3$. Gene 118:115-120

Reiter B, Oram JD (1963) Group N streptococcal phage lysin. J Gen Microbiol 32:29-32

Romero A, Lopez R, Garcia P (1990a) Characterization of the pneumococcal bacteriophage HB-3 amidase: cloning and expression in Escherichia coli. J Virol 64:137-142

Romero A, Lopez R, Garcia P(1990b) Sequence of the Streptococcus pneumoniae bacteriophage HB-3 amidase reveals high homology with the major host autolysin. J Bacteriol 172:5064-5070

Sanders ME, Leonhard PJ, Sing GWD, Klaenhammer TR (1986) Conjugal strategy for construction of fast acid-producing, bacteriophage resistant lactic streptococci for use in dairy fermentations. Appl Environ Microbiol 52:1001-1007

Schleifer KH, Kraus J, Dvorak C, Kilpper-Bälz R, Collins MD, Fisher W (1985) Transfer of Streptococcus lactis and related streptococci to the genus Lactococcus gen. nov. Syst Appl Microbiol 6:183-195 
Sechaud L (1990) Caractérisation de 35 bactériophages de $\mathrm{Lac}$ tobacillus helveticus. Thèse INRA, Jouy-en-Josas, France

Sechaud L, Cluzel PJ, Rousseau M, Baumgartner A, Accolas JP (1988) Bacteriophages of lactobacilli. Biochimie 70:401-410

Shearman CA, Underwood H, Jury K, Gasson M (1989) Cloning and DNA sequence analysis of a Lactococcus bacteriophage lysin gene. Mol Gen Genet 218:214-221

Shearman CA, Hertwig S, Teuber M, Gasson MJ (1991) Characterization of the prolate-headed lactococcal bacteriophage $\phi$ vML3: location of the lysin gene and its DNA homology with other prolate-headed phages. J Gen Microbiol $137: 1285-1291$

Shearman CA, Jury K, Gasson MJ (1992) Autolytic Lactococcus lactis expressing a lactococcal bacteriophage lysin gene. Biotechnology 10:196-199

Shin C, Sato Y (1980) Leuconostoc phage-associated lysin acting on lactic acid bacteria. Jpn J Zootech Sci 51:443-446

Teuber M, Lembke J (1983) The bacteriophages of lactic acid bacteria with emphasis on genetic aspects of group $\mathrm{N}$ lactic streptococci. Antonie van Leeuwenhoek J Microbiol Serol 49:283-295

Thomas TD, Jarvis BDW, Skipper NA (1974) Localization of proteinase(s) near the cell surface of Streptococcus lactis. J Bacteriol 118:329-333

Tourville DR, Johnstone DB (1966) Lactic streptococcal phageassociated lysin. I. Lysis of heterologous lactic streptococci by a phage-induced lysin. J Dairy Sci 49:158-162

Tourville DR, Tokuba S (1967) Lactic streptococcal phage-associated lysin. II. Purification and characterization. J Dairy Sci 50:1019-1024

Trautwetter A, Ritzenthaler P, Alatassova T, Mata-Gilsinger M (1986) Physical and genetic characterization of the genome of Lactobacillus lactis bacteriophage LL-H. J Virol 59:551-555
Valyasevi R, Sandine WE, Geller BL (1990) The bacteriophage kh receptor of Lactococcus lactis subsp. cremoris $\mathrm{KH}$ is the rhamnose of the extracellular wall polysaccharide. Appl Environ Microbiol 56:1882-1889

Ward JB, Curtis CAM, Taylor C, Buxton RS (1982) Purification and characterization of two phage PBSX-induced lytic enzymes of Bacillus subtilis 168: an $N$-acetylmuramoyl-L-amidase and an $N$-acetylmuramidase. J Gen Microbiol 128:1171-1178

Ward LJH, Bresford TPJ, Lubbers MW, Jarvis BDW, Jarvis AW (1993) Sequence analysis of the lysin gene region of the prolate lactococcal bacteriophage $\mathrm{c} 2$. Can $\mathrm{J}$ Microbiol 39:767-774

Watanabe K, Hayashida M, Ishibashi K, Nakashima Y (1984a) An $\mathrm{N}$-acetylmuramidase induced by PL-1 phage infection of $\mathrm{Lac}$ tobacillus casei. J Gen Microbiol 130:275-277

Watanabe K, Oshibashi K, Nakashima Y, Sakurai Y (1984b) A phage-resistant mutant of Lactobacillus casei which permits phage adsorption but not genome injection. J Gen Virol 65:981-986

Watanabe K, Hayashida M, Nakashima Y, Hayashi S (1987) Preparation and regeneration of bacteriophage PL-1 enzyme-induced Lactobacillus casei protoplasts. Appl Environ Microbiol $53: 2686-2688$

Watanabe K, Kakita Y, Nakashima Y, Miake F (1992) Calcium requirement for protoplast transfection mediated by polyethylene glycol of Lactobacillus casei by PL1 phage DNA. Biosci Biotechnol Biochem 56:1859-1862

Whitehead HR, Cox GA (1935) Bacteriophage phenomena in cultures of lactic streptococci. J Dairy Res 7:55-62

Yokokura T (1977) Phage receptor material in Lactobacillus casei. J Gen Microbiol 100:139-145

Young RY (1992) Bacteriophage lysis: mechanism and regulation. Microbiol Rev 56:430-481 